\title{
Distill Stalk End Feeding (Bunch Feeding) can Improve the Quality and Yield of Banana cv. Robusta (AAA-Group) under Hill Zone of Karnataka (Zone-09)
}

\author{
H.S. Sreekanth ${ }^{1}$, D. Thiphesha ${ }^{2}$, K. Padmanabha ${ }^{1}$, G.M. Vinay ${ }^{1}$, \\ A. P. Shivakumar ${ }^{1}$ and B.G. Jashmitha ${ }^{1}$ \\ ${ }^{1}$ Department of Fruit Science, ${ }^{2}$ Department of Vegetable Science \\ College of Horticulture, Bengaluru, University of Horticulture Sciences, Bagalkot, \\ Karnataka, India- 587104 \\ *Corresponding author
}

\section{A B S T R A C T}

\begin{tabular}{|c|}
\hline Keywords \\
\hline $\begin{array}{l}\text { Bunch, Feeding, } \\
\text { Banana, Robusta, } \\
\text { Fingers, Hands, Hill } \\
\text { Zone, yield and } \\
\text { Quality }\end{array}$ \\
\hline Article Info \\
\hline $\begin{array}{l}\text { Accepted: } \\
\text { 20 July } 2018 \\
\text { Available Online: } \\
10 \text { August } 2018\end{array}$ \\
\hline
\end{tabular}

An experiment was conducted at farmer field to determine the effect of different bunch stalk feeding with different growth regulators on yield of banana $c v$. Robusta (AAA-group) under hill zone of Karnataka. The experiment was laid in RCBD with 16 treatments and three replications. Urea (2.0, 4.0 and $6.0 \%)$, sulphate of potash $(1.5,2.0$ and $2.5 \%), 2,4-$ $\mathrm{D}(10,20$ and $30 \mathrm{ppm})$, panchagavya $(2.0,4.0$ and $6.0 \%)$ and banana special $(0.2,0.4$ and $0.6 \%$ ) and compared with control (without bunch stalk feeding). Results revealed that, at the time of harvest, bunch fed with 2 per cent sulphate of potash recorded significantly yield characters such has highest intermodal length $(8.93 \mathrm{~cm})$, bunch length $(85.20 \mathrm{~cm})$, finger girth $(12.79 \mathrm{~cm})$, finger weight $(170.10 \mathrm{~g})$, weight of hands $(2.60 \mathrm{~kg})$, weight of bunch $(24.21 \mathrm{~kg})$, total yield $(60.53 \mathrm{t} / \mathrm{ha})$ and benefit cost ratio (2.68). Significant results on quality characters observed in bunch fed with 2.5 per cent sulphate of potash recorded significantly lowest physiological loss in weight (10.44\%), more days to ripe (14.33 days) under ambient condition, longer shelf life (8.67 days), highest total sugars (18.49\%), less titratable acidity $(0.25 \%)$, highest Sugar : acid ratio (73.14), reducing sugar $(15.86 \%)$ and non reducing sugar $(2.63 \%)$ compared to control (13.20\%, 10.67 days, 6.67 days, 15.21 $\%, 0.33 \%, 45.62,13.01 \%$ and $2.20 \%$ respectively). Bunches fed with 2.0 per cent sulphate of potash recorded significantly highest pulp weight $(109.16 \mathrm{~g})$, peel weight $(42.31 \mathrm{~g})$, pulp to peel ratio (2.58) and TSS (23.51 ${ }^{0}$ Brix) compared to control (90.81 g, $38.00 \mathrm{~g}, 2.39$ and $19.88{ }^{0}$ Brix respectively).

\section{Introduction}

Banana is one of the major commercial fruit crops grown in tropics, subtropics and considered as one of the most economical source of food. In India bananas are cultivated in an area of 8.3 lakh hectares and producing
29.78 Million tones and 1.2 lakh hectares and production of 2.28 Million tonnes in Karnataka, with average national and state productivity of $35.9 \mathrm{MT} / \mathrm{ha}$ and $20.4 \mathrm{MT}$ /ha respectively (Anon., 2011) With average national and state productivity of $35.9 \mathrm{MT} / \mathrm{ha}$ and 20.4 MT/ha respectively (Anon., 2011). 
Banana plant is supplied with nutrients through soil and foliage, denavelling (removal of male inflorescence for nutrient diversion) and post-shooting feeding nutrients through the distal stalk-end of rachis (Venkatarayappa et al., 1976, Prasanna Kumari Amma et al., 1986, Ancy et al., 1998 and Ancy and Kurien, 2000) to achieve high yields. De - navelling serves du al purposes of saving mobilization of food into unwanted sink of banana plant as well as earning additional income when excised male bud is used as a vegetable (Singh, 2001). Therefore, an attempt was made to enhance the bunch yield by feeding Urea, sulphate of potash (SOP), 2,4D, panchagavya and Banana special (micronutrient mixture) through the excised distal stalk-end of rachis after de-navelling and to determine influence of treatments on quality of "Robusta" banana.

\section{Details of treatments in the study as fallows}

$\mathbf{T}_{1-}$ Control (without bunch stalk feeding)

$\mathbf{T}_{2}$ - Urea - $2 \%$

$\mathbf{T}_{\mathbf{3}}$ - Urea - $4 \%$

$\mathbf{T}_{4}$ - Urea - $6 \%$

$\mathbf{T}_{\mathbf{5}}$ - Sulphate of Potash $-1.5 \%$

$\mathbf{T}_{6-}$ - Sulphate of Potash $-2.0 \%$

$\mathbf{T}_{7}$ - Sulphate of Potash - $2.5 \%$

$\mathbf{T}_{\mathbf{8}}-2$, 4-D - 10ppm

$\mathbf{T}_{\mathbf{9}}-2$, 4-D - 20ppm

$\mathbf{T}_{\mathbf{1 0}}$-2, 4-D - 30ppm

$\mathbf{T}_{11}$ - Panchagavya - $2 \%$

T12- Panchagavya - $4 \%$

$\mathbf{T}_{13}$ - Panchagavya - $6 \%$

$\mathbf{T}_{\mathbf{1 4}}$ - Banana special - $0.2 \%$

$\mathbf{T}_{\mathbf{1 5}}$ - Banana special - $0.4 \%$

$\mathbf{T}_{\mathbf{1 6}}$ - Banana special - $0.6 \%$

\section{Materials and Methods}

The experiment was conducted in the farmer field during the year 2011-2012 at Palguni village (Tq. Mudigere, Dist. Chikmagalur) which situated at $13^{\circ}$ North latitude and $77^{\circ}$
38 'East longitude at an altitude of $980 \mathrm{~m}$ above mean sea level in the hill zone (Zone 9) of Karnataka state with an average rainfall of $3833.40 \mathrm{~mm}$ annual average temperature of the area varies from 27.0 to $36.6{ }^{\circ} \mathrm{C}$. The soil was sandy clay loam and slightly acidic in nature ( $\mathrm{pH} 5.70$ ) with safe level of $0.35 \mathrm{dSm}^{-1}$ electrical conductivity (EC) and high in organic carbon content $(1.70 \%)$. The experiment was laid in the existing plantation, spaced at $2.2 \times 1.2 \mathrm{~m}$., the land was ploughed twice and harrowed to bring it to good tilth. Uniform sized suckers had been procured from previously grown crop in the same farm. Before a week of planting $20 \mathrm{~kg}$ of well decomposed farm yard manure (FYM) was added to each pit. Inorganic fertilizers were applied at $2^{\text {nd }}, 4^{\text {th }}$ and $6^{\text {th }}$ months after planting with recommended dose per plant (180: 108: $225 \mathrm{~g} \mathrm{~N} \mathrm{P} \mathrm{K)} \mathrm{and} \mathrm{no} \mathrm{further}$ organic and inorganic fertilizers were applied at $7^{\text {th }}$ month after planting. Protective irrigation was given at weekly intervals. The experiment was laid out in RCBD with 16 treatments replicated twice. Total no of plots were 16 per each replication. Out of 9 plants in a plot, 3 plants were selected for recording observation. For bunch stalk feeding, uniform bunches from each treatment were selected. Rachis at the distal end of the bunch was excised along with male bud giving a slant cut (De-navelling by excision of rachis $10 \mathrm{~cm}$ after the last hand) immediately after all the pistillate (female) flowers had set fruits i.e., after four bracts were shed (about 15 days after flower emergence). The prepared $250 \mathrm{ml}$ solution was placed in a thick polythene bag and tied securely by dipping the excised rachis and maintained till harvest.

The finger characters namely, length, girth and finger weight, were measured in ' $D$ ' finger, i.e. middle finger in top row of the second hand (Gottreich et al., 1964). The bunches were harvested when the fingers had fully developed and devoid of any ridges on 
its surface of the fruit and weighed and the bunch weight was expressed in kilogram. Weight of hand was recorded by weighing middle hand from the labeled plants and taken average and was expressed in kilogram. The plant yield was calculated by multiplying the yield per plant with the total number of plants per hectare and expressed in tonnes per hectare.

The Physiological loss in weight of fruits was expressed in percent loss of weight from day of harvest to $7^{\text {th }}$ day after harvest. The fully matured hands were taken and kept for ripening under ambient condition and the days taken for ripening was recorded. Days to ripe (Green life) has been defined as the time a harvested fruit takes to reach maturity under defined conditions (Turner, 1997). Shelf life of fruits was decided based on the appearance and marketability of the fruits. When the fruits attained beyond edible ripe stage, then those fruits were considered to have reached the end of their shelf life.

The Shelf life can be defined as the time over which the ripe fruit remains acceptable for consumption (Turner, 1997). The reducing sugar and total sugar content of the fruit was estimated by following the method of Ranganna (1977). The percentage of nonreducing sugars was obtained by subtracting the percentage of reducing sugars from the total sugars. The standard method of A.O.A.C. (1960) was followed to estimate the acidity. The acidity of the fruit and was expressed as percentage of citric acid on fresh weight of sample. The Sugar/acid ratio of the pulp was arrived at by dividing the value of total sugars by that of acidity and this was reckoned as a measure of fruit quality. The total soluble solids was recorded with the extracted juice using a 'Zeiss' hand refractometer at room temperature and expressed in percentage.
The pulp weight and peel weight were recorded separately from the ripened fruits and expressed in grams. The pulp to peel ratio was worked out by dividing the mean weight of pulp by mean weight of peel. The data in respect of all the above parameters were tabulated and subjected to the statistical analysis using methods of analysis of variance (ANOVA) for randomized block design by Fisher and Yates (1963). Whenever ' $F$ ' test was found significant for comparing the means of two treatments critical difference (C.D. at $5 \%$ ) were worked out.

\section{Results and Discussion}

The maximum internodal length $(8.93 \mathrm{~cm})$ between hands of the bunch and length of bunch $(85.20 \mathrm{~cm})$ was obtained in the treatment (T6) supplied with 2 per cent sulphate of potash, The increased length of bunch and inter nodal length might be due to the cell division and cell expansion by their effect on RNA and DNA synthesis, this was in conformity with the findings of Nalina and Kumar (2007) in $c v$. Robusta. The length of finger was increased $(21.96 \mathrm{~cm})$ in the treatment $\left(T_{3}\right)$ where the bunch fed with 4 per cent urea. The increase in the length of fruit was in turn reflected in finger weight in all most all treatments. The results were in close conformity with Ancy and Kurien (2000) in $c v$. Nendran and Nandan et al., (2011) in $c v$. Nanjangudu rasabale (AAB). It can be inferred that, the nutrient supplied in the form of urea was utilized more for cell elongation of the fruits rather than cell multiplication and the cell enlargement which resulted in more length than girth. The urease activity also coincided with lengthening of fruits as reported by Ancy et al., (1998).

The results pertaining to girth of fingers shown that, the bunch fed with 2 per cent sulphate of potash $\left(\mathrm{T}_{6}\right)$ gave a better result $(12.79 \mathrm{~cm})$. The increase in girth intern 
reflected on final weight of the finger, which clearly indicated that potassium is involved in cell enlargement rather than cell division as there was not much increase in length of fruit when compared to other treatments. The increase in finger girth by 2 per cent sulphate of potash might be due to the exogenous potassium supply which acted as an activator of several enzymes. Potassium also had a role in synthesizing the precursor of chlorophyll pigments. Presence of sulphur in sulphate of potash has a synergistic effect with zinc which is essential for cabon dioxide absorption and utilization, synthesis of RNA and auxin which increased the size of fruit. Similar observations made by Mustaffa et al., (2004) in $c v$. Nendran, Ramesh and Kumar (2007) in $c v$. Neypoovan and Nandan et al., (2011) in $c v$. Nanjanagudu Rasabale.

The bunch fed with 2 per cent sulphate of potash (T6) recorded the maximum finger weight $(170.10 \mathrm{~g})$ which was on par with 0.6 per cent banana special $\left(\mathrm{T}_{16}\right)$ and 4 per cent urea $\left(\mathrm{T}_{3}\right)$ which resulted in mean fruit weight of $168.80 \mathrm{~g}$ and $166.50 \mathrm{~g}$ respectively (Table 1). Similar results on fruit weight were found by Venkatarayappa (1975), who reported that application of urea as a spray in Dwarf Cavendish and Giant cavendish over control by 14.80 per cent and 17.24 per cent respectively and Ramesh and Kumar (2007 and 2010) in $c v$. Neypoovan, Nandan et al., (2011) in Nanjanagudu Rasabale and Ramesh et al., (2008) in $c v$. Robusta. The increase in finger weight by urea 4 per cent can be supported with the findings by Calvin et al., (1952), Mothes (1961) and Harper (1984), who reported that in plants alointoin and allantonic acid seems to be more immediately concerned with the synthesis and use of nitrogen they contain and these compounds may be derived from glycoxylic acid with urea as a possible donor (non urease pathway). In a study on the morphophysiological aspects of finger development it was observed that, in the final stage of development, cell enlargement took place thus reducing the available air space followed by starch filling in the cells. The late application of urea, coinciding with or after the stages of cell division, when the early nitrogen pool becomes exhausted, may be involved in fruit development as a nitrogen source (Kurien et al., 1999). The results were in close conformity with Ancy and Kurien (2000) in $c v$. Nendran.

The increased yield and yield parameters influenced by increase in girth, length and weight of individual fingers (Table 1). Bunch feeding with 2 per cent sulphate of potash $\left(\mathrm{T}_{6}\right)$ which showed higher girth and weight of finger finally resulted in highest weight of hands $(2.60 \mathrm{~kg})$, weight of bunch $(24.21 \mathrm{~kg})$ and total yield (60.53 t/ha), which was on par with $\left(\mathrm{T}_{16}\right) 0.6$ per cent banana special $(2.55$ $\mathrm{kg}, 23.75 \mathrm{~kg}$ and $59.39 \mathrm{t} / \mathrm{ha}$ respectively), $\left(\mathrm{T}_{3}\right)$ 4 per cent urea $(2.54 \mathrm{~kg}, 23.64 \mathrm{~kg}$ and 59.11 t/ha respectively), $\left(\mathrm{T}_{5}\right) 1.5$ per cent sulphate of potash $(2.53 \mathrm{~kg}, 23.53 \mathrm{~kg}$ and $58.82 \mathrm{t} / \mathrm{ha}$ respectively) and $\left(\mathrm{T}_{15}\right) 0.4$ per cent banana special $(2.52 \mathrm{~kg}, 23.35 \mathrm{~kg}$ and $58.68 \mathrm{t} / \mathrm{ha}$ respectively) weight of hands, bunch and total yield respectively, Increase in the weight of hand, weight of bunch and yield is due to Sulphur present in the sulphate of potash (SOP) might be responsible for the formation of ferridoxin (Iron - sulphur protein) in plants which might have a direct impact in activating the catalase and peroxidase enzymes. Presence of sulphur in SOP had a synergistic effect with zinc, which is essential for carbon dioxide absorption and utilization, synthesis of RNA and auxin. Sulphur can increase the absorption of potassium or it can react with nitrogen and potassium (Farrag et al., 1990). Sulphur helps in energy transformation and activation of enzymes in carbohydrate metabolism and subsequently greater partitioning of photosynthates. Sulphur application increased the yield since it is a 
constituent of amino acid and protein production (Ahmed et al., 1998). The influence of sulphur in enhancing fruit yield in bananas was stressed by Lahav and Turner (1983). SOP also triggered the maximum nitrate reductase in the majority of growth stages. Since nitrate reductase is the key enzyme of nitrate assimilation, the maintenance of the high rate of enzyme activity is imperative for enhanced protein content of the plants. The role of the $\mathrm{K}+$ ion in this enzyme activity was stressed by Evans and Sorger (1966). Soluble protein is considered as an indirect measure of Ribulose-1, 5-bisphosphate RuBP carboxylase activity as the enzyme constitutes more than 60 per cent of the soluble protein content and hence, it serves as an indicator of the photosynthetic rate (Evans et al., 1975). RuBP carboxylase, the prime enzyme of carbon fixation is dominant the soluble protein fraction of leaves and therefore is known as the most abundant protein in the world (Noggle and Fritz, 1986). The present findings are in close conformity with Alagarsamy and Neelakandan (2008) in $c v$. Robusta, Ramesh and Kumar (2007 and 2010) in $c v$. Neypoovan and Ramesh et al., (2008) in $c v$. Robusta.

In bunch stalk feeding of urea, has an higher urease activity coincided with better bunch and finger grade which revealed the possibility of conversion or hydrolysis of urea into ammonia $\left(\mathrm{NH}_{3}\right)$ and carbon dioxide $\left(\mathrm{CO}_{2}\right)$ and its better absorption and assimilation (urease pathway). This enzyme activity in turn, is related with the molecular absorption of urea (Ancy et al., 1998). The released $\mathrm{NH}_{3}$ would be incorporated into amino acids and then into protein via the glutamate synthase cycle (Kumar and Abrol, 1990). Similarly, this study was supported by Ancy and Kurien (2000) in $c v$. Nendran and Kotur and Keshava (2008) in $c v$. Robusta. Increase in the yield by banana special (micronutrient mixture) might be due to important role of micronutrients in increasing the cell elongation and division as suggested by Abdel et al., (1992). These findings were agreed with results reported by Yadlod and Kadam (2008a) in $c v$. Ardhapuri, Yadlod and Kadam (2008b) in $c v$. Grand Naine and Pathak et al., (2011) in $c v$. Martaman (AAB, Silk).

Results revealed that quality parameter at the time of harvest, bunch fed with 2.5 per cent sulphate of potash recorded significantly lowest physiological loss in weight (10.44 \%), more days to ripe (14.33 days) under ambient condition, longer shelf life (8.67 days), highest total sugars (18.49\%), less titratable acidity $(0.25 \%)$, highest Sugar : acid ratio (73.14), reducing sugar $(15.86 \%)$ and non reducing sugar $(2.63 \%)$ (Table 2$)$.

Ramesh and Kumar, 2010 reported that extended shelf life by bunch fed with sulphate of potash might be due to the lesser Physiological loss in weight experienced in fruits. Similarly, the extended shelf life was found in Ney Poovan banana by Ramesh and Kumar (2007 and 2010) by spraying $1.5 \%$ sulphate of potash, Kumar et al., (2008) in Robusta, Nandan et al., (2011) in $c v$. Nanjanagudu Rasabale and Sateesh and Bangarusamy (2006) in $c v$. Rasthali by spraying $1 \%$ potassium chloride.

Days to ripe of harvested fruit are an important attribute decides the market value of the produce. It is desired to have longer days to ripe to withstand longer transit time from field to consumer.

However, more number of days to ripe was noticed in the bunches fed with $2.5 \%$ sulphate of potash $\left(\mathrm{T}_{7}\right)$ which remained green till 14.33 days, and lesser days to ripe was noticed in urea $6 \%\left(\mathrm{~T}_{4}\right)$ which remained green only for 9.33 days. Reduced number of days to ripe in $6 \%$ urea might be due to high $\mathrm{N}$ content of fruits accelerated ripening by 
promoting autocatalytic ethylene synthesis, which might be the reason for early ripening of fruits in urea sprayed treatments in banana, this were opined by Dominguez and Vendrell (1993). These results were supported by Sateesh and Bangarusamy (2006) by 4 per cent urea spraying in $c v$. Rasthali. High levels of $\mathrm{N}$ have been shown to reduce green life (days to ripe) (Turner, 1997).

Application of sulphate of potash was also found to be good in increasing sugar per cent as potassium plays a major role in carbohydrates synthesis, breakdown and translocation and synthesis of protein and neutralization of physiologically important organic acids. This finding agreed with that of Tisdale and Nelson (1966). Going further, potassium when supplied in the form of sulphate of potash favours conversion of starch into simple sugars during ripening by activating the sucrose synthatase enzyme thus resulting in higher sugar percentage. Potassium is involved in phloem loading and unloading of sucrose and amino acids, and storage in the form of starch in developing fruits by activating the enzyme starch synthase (Mengel and Kirkby, 1987). In plants supplied with potassium, the osmotic potential of the phloem sap and the volume flow are higher than in bunches with low $\mathrm{K}$ supply, and as a result, sucrose concentration in content of fruits is increased (Marschner, 1995). Similar results were found by Ramesh and Kumar (2007 and 2010) in banana $c v$. Neypoovan, Nandan et al., (2011) in $c v$. Nanjanagudu Rasabale and Ramesh et al., (2008) in $c v$. Robusta. Enhanced quality of fruits particularly the sugar content may be due to the role of sulphate $\left(\mathrm{SO}_{4}\right)$ ions released from sulphate of potash as sulphate favours, while chloride reduces, the activity of anabolic enzymes, resulting in accumulation of highly polymerized carbohydrates (starch), which would have subsequently disintegrated into sugars on ripening (Alagarsamy et al., 2008).
Increased level of potassium application results in reduced acid content of fruits. This could be due to the fact that under low potassium regime, phosphoenol pyruvate (PEP) was apparently shunted into alternate pathways resulting in a shortage of acetyl COA (Pattee and Teel, 1967). Hence, oxalo acetate appeared to be preferentially formed from PEP in plants with low levels of potassium and this organic acid derivative accumulated. Neutralization of organic acids due to a high potassium level in tissues could have also resulted in the reduction in acidity (Tisdale and Nelson 1966).This results were agreed with Nalina and Kumar 2007 in $c v$. Robusta, Ramesh and Kumar (2007 and 2010) in $c v$. Neypoovan, Ramesh et al., (2008) in $c v$. Robusta and Nandan et al., (2011) in $c v$. Nanjanagudu Rasabale. In this context we can recall that the control treatment which recorded highest acid percentage $(0.33 \%)$ also showed lowest total sugar percentage (15.21\%). Meanwhile, maximum sugar to acid ratio (73.14) was obtained in treatment $\left(\mathrm{T}_{7}\right)$ with $2.5 \%$ sulphate of potash and minimum sugar to acid ratio (45.62) was obtained in $\left(\mathrm{T}_{1}\right)$ control.

Bunch fed with 2.0 per cent sulphate of potash recorded significantly highest pulp weight (109.16 g), peel weight (42.31 g), pulp to peel ratio (2.58) and TSS (23.51 0Brix). As such Robusta pulp is very thick and they become still thicker at the edible stage. This indicates the beneficial role of potassium and panchagavya to get good pulp recovery. This might be due to less experienced physiological loss in weight by fruits may contribute towards the more pulp weight. The results were in conformity with those obtained by Kumar et al., (2008) in Robusta, Nandan et al., (2011) in $c v$. Nanjanagudu Rasabale and Ramesh and Kumar et al., (2007 and 2010) in $c v$. Neypoovan. 
Table.1 Effect of bunch feeding on bunch characters and yield of Banana cv. Robusta

\begin{tabular}{|c|c|c|c|c|c|c|c|c|}
\hline Treatments & $\begin{array}{l}\text { Internodal } \\
\text { length }(\mathrm{cm})\end{array}$ & $\begin{array}{l}\text { Bunch } \\
\text { length (cm) }\end{array}$ & $\begin{array}{l}\text { Length of } \\
\text { finger }(\mathrm{cm})\end{array}$ & $\begin{array}{l}\text { Girth of } \\
\text { finger }(\mathbf{c m})\end{array}$ & $\begin{array}{l}\text { Weight of } \\
\text { finger }(g)\end{array}$ & $\begin{array}{l}\text { Weight of } \\
\text { hand (kg) }\end{array}$ & $\begin{array}{l}\text { Weight of } \\
\text { bunch }(\mathrm{kg})\end{array}$ & $\begin{array}{l}\text { Yield } \\
\text { (t/ha.) }\end{array}$ \\
\hline $\mathrm{T}_{1}-$ Control & 7.90 & 74.20 & 16.79 & 10.13 & 148.40 & 2.21 & 20.56 & 51.39 \\
\hline $\mathrm{T} 2$ - Urea - $2 \%$ & 8.43 & 79.98 & 18.90 & 11.51 & 160.80 & 2.49 & 22.37 & 55.92 \\
\hline T3 - Urea - $4 \%$ & 8.83 & 83.18 & 21.96 & 12.30 & 166.50 & 2.54 & 23.64 & 59.11 \\
\hline T4 - Urea - $6 \%$ & 7.97 & 75.23 & 17.06 & 10.69 & 152.90 & 2.36 & 21.27 & 53.18 \\
\hline T5 - Sulphate of Potash - $1.5 \%$ & 8.77 & 82.10 & 20.77 & 12.24 & 165.20 & 2.53 & 23.53 & 58.82 \\
\hline T6 - Sulphate of Potash - $2.0 \%$ & 8.93 & 85.20 & 21.67 & 12.79 & 170.10 & 2.60 & 24.21 & 60.53 \\
\hline T7 - Sulphate of Potash - $2.5 \%$ & 8.33 & 78.23 & 18.53 & 11.25 & 160.30 & 2.46 & 22.17 & 55.43 \\
\hline $\mathrm{T} 8$ - 2, 4-D - 10ppm & 8.03 & 75.78 & 17.33 & 10.82 & 154.03 & 2.37 & 21.36 & 53.40 \\
\hline T9 - 2, 4-D - 20ppm & 8.13 & 76.20 & 17.57 & 10.98 & 155.80 & 2.39 & 21.48 & 53.71 \\
\hline $\mathrm{T} 10-2,4-\mathrm{D}-30 \mathrm{ppm}$ & 8.23 & 77.98 & 18.07 & 11.13 & 159.10 & 2.42 & 21.79 & 54.47 \\
\hline T11 - Panchagavya - $2 \%$ & 8.17 & 76.77 & 17.87 & 11.07 & 158.50 & 2.41 & 21.66 & 54.15 \\
\hline T12 - Panchagavya - $4 \%$ & 8.57 & 80.20 & 19.13 & 11.69 & 161.70 & 2.50 & 22.47 & 56.16 \\
\hline T13 - Panchagavya - $6 \%$ & 8.63 & 80.87 & 20.23 & 11.92 & 162.30 & 2.51 & 22.62 & 56.55 \\
\hline $\mathrm{T}_{14}-$ Banana special $-0.2 \%$ & 8.27 & 78.10 & 18.23 & 11.16 & 159.80 & 2.45 & 22.03 & 55.08 \\
\hline $\mathrm{T}_{15}-$ Banana special $-0.4 \%$ & 8.73 & 81.93 & 20.47 & 12.11 & 163.40 & 2.52 & 23.35 & 58.68 \\
\hline $\mathrm{T}_{16}-$ Banana special $-0.6 \%$ & 8.87 & 83.80 & 21.27 & 12.42 & 168.80 & 2.55 & 23.75 & 59.39 \\
\hline F- test & $* *$ & *** & *** & *** & $* *$ & $* *$ & *** & *** \\
\hline S.Em \pm & 0.11 & 1.18 & 0.40 & 0.19 & 1.35 & 0.04 & 0.42 & 1.05 \\
\hline $\mathrm{CD}$ at $5 \%$ & 0.30 & 3.40 & 1.17 & 0.56 & 3.89 & 0.12 & 1.22 & 3.04 \\
\hline
\end{tabular}


Table.2 Effect of bunch feeding on quality parameters of banana $c v$. Robusta

\begin{tabular}{|c|c|c|c|c|c|c|c|c|c|}
\hline Treatments & $\begin{array}{l}\text { Total sugars } \\
(\%)\end{array}$ & $\begin{array}{l}\text { Titratable } \\
\text { acidity }(\%)\end{array}$ & $\begin{array}{l}\text { Sugar : acid } \\
\text { ratio }\end{array}$ & $\begin{array}{l}\text { TSS } \\
\left({ }^{0} \text { Brix }\right)\end{array}$ & $\begin{array}{l}\text { Reducing } \\
\text { sugar }(\%)\end{array}$ & $\begin{array}{l}\text { Non-reducing } \\
\text { sugars }(\%)\end{array}$ & $\begin{array}{l}\text { Pulp } \\
\text { weight (g) }\end{array}$ & $\begin{array}{l}\text { Peel } \\
\text { weight (g) }\end{array}$ & $\begin{array}{l}\text { Pulp to peel } \\
\text { ratio }\end{array}$ \\
\hline $\mathrm{T}_{1}-$ Control & 15.21 & 0.33 & 45.62 & 19.88 & 13.01 & 2.20 & 90.81 & 38.00 & 2.39 \\
\hline $\mathrm{T} 2$ - Urea - $2 \%$ & 16.98 & 0.32 & 53.24 & 20.41 & 14.63 & 2.35 & 99.06 & 40.11 & 2.47 \\
\hline T3 - Urea - $4 \%$ & 17.65 & 0.30 & 58.86 & 22.17 & 15.18 & 2.47 & 102.47 & 41.15 & 2.49 \\
\hline T4 - Urea - $6 \%$ & 17.05 & 0.31 & 55.02 & 20.43 & 14.71 & 2.34 & 93.47 & 38.15 & 2.45 \\
\hline T5 - Sulphate of Potash - $1.5 \%$ & 18.26 & 0.27 & 66.96 & 23.08 & 15.69 & 2.57 & 105.09 & 41.71 & 2.52 \\
\hline T6 - Sulphate of Potash - $2.0 \%$ & 18.41 & 0.26 & 70.09 & 23.51 & 15.80 & 2.61 & 109.16 & 42.31 & 2.58 \\
\hline T7 - Sulphate of Potash - $2.5 \%$ & 18.49 & 0.25 & 73.14 & 23.11 & 15.86 & 2.63 & 102.66 & 40.91 & 2.51 \\
\hline T8 - 2, 4-D - 10ppm & 16.81 & 0.31 & 54.91 & 20.44 & 14.54 & 2.27 & 95.12 & 38.98 & 2.44 \\
\hline T9 - 2, 4-D - 20ppm & 17.15 & 0.30 & 57.88 & 20.73 & 14.79 & 2.36 & 96.07 & 39.21 & 2.45 \\
\hline T10 - 2, 4-D - 30ppm & 17.28 & 0.29 & 60.38 & 20.96 & 14.84 & 2.44 & 97.81 & 39.78 & 2.46 \\
\hline T11 - Panchagavya - $2 \%$ & 17.54 & 0.28 & 62.89 & 22.98 & 15.03 & 2.51 & 99.64 & 39.86 & 2.50 \\
\hline T12 - Panchagavya - $4 \%$ & 17.95 & 0.27 & 66.75 & 23.08 & 15.41 & 2.54 & 102.75 & 40.79 & 2.52 \\
\hline T13 - Panchagavya - $6 \%$ & 18.14 & 0.26 & 70.04 & 23.18 & 15.55 & 2.59 & 104.23 & 41.03 & 2.54 \\
\hline $\mathrm{T}_{14}-$ Banana special $-0.2 \%$ & 17.42 & 0.30 & 58.78 & 22.77 & 14.94 & 2.47 & 99.15 & 40.31 & 2.46 \\
\hline $\mathrm{T}_{15}-$ Banana special - $0.4 \%$ & 17.72 & 0.29 & 61.16 & 22.99 & 15.23 & 2.49 & 102.17 & 40.88 & 2.50 \\
\hline $\mathrm{T}_{16}-$ Banana special $-0.6 \%$ & 18.03 & 0.27 & 65.98 & 23.18 & 15.46 & 2.57 & 106.15 & 42.21 & 2.52 \\
\hline F- test & $* *$ & $* *$ & $* *$ & $* *$ & $* *$ & $* *$ & $* *$ & $* *$ & $* *$ \\
\hline S.Em \pm & 0.14 & 0.01 & 1.99 & 0.18 & 0.13 & 0.06 & 0.87 & 0.39 & 0.02 \\
\hline $\mathrm{CD}$ at $5 \%$ & 0.40 & 0.02 & 5.74 & 0.51 & 0.38 & 0.16 & 2.50 & 1.13 & 0.05 \\
\hline
\end{tabular}

** Highly significant 
The total soluble solids (TSS) a prime factor which determine the quality of fruits. Nandan et al., (2011) reported that increase in TSS shows that sulphate of potash when supplied exogenously increased the flow of plant assimilates into the developing fruits especially when assimilate flow from other parts of plant becomes limited in banana $c v$. Nanjangudu rasabale. The findings were closely conformity with Ramesh and Kumar (2007 and 2010) in $c v$. Neypoovan and Ramesh et al., (2008) in $c v$. Robusta.

From the above study it is concluded that distill end stalk feeding (bunch feeding) 2.0 per cent of sulphate of potash increased the yield by 17.79 per cent (60.53 t/ha). While, 2 and 2.5 per cent sulphate of potash improved almost all quality parameters of banana $c v$. Robusta under hill zone of Karnataka.

\section{References}

Abdel Kadar, A. M., El-makhtum, F. M. B. and Baskawros, M. B., 1992, Effect of micronutrients foliar application on vegetative growth and yield of Hindi banana. Egyptian J. agric., 70 (2): 613624.

Ahmed, M. K., Aditya, D. K. and Siddique, M. A., 1998, Effect of $\mathrm{N}$ and $\mathrm{S}$ application on the growth and yield of onion $c v$. FaridpurBhatti. Bangladesh Hort., 16 (1): 36- 41.

Alagarsamy Ramesh Kumar and Neelakandan Kumar, 2008, Studies on the efficacy of sulphate of potash (SOP) on the physiological, yield and quality parameters of banana $c v$. Robusta (Cavendish- AAA). Eur. Asian J. BioSci., 2 (12): 102-109.

Ancy, K. and Kurien, S., 2000, Bunch stalk feeding of Urea in banana Musa (AAB group) 'Nendran'. Sci. Hort., 84: 205212.

Ancy, T. K., Kurien, S. Augustin, A. and
Balachandran, P. V., 1998, Urease activity in banana fruit. J. Pl. Nutr., 21 (10): 2127-2140.

Anonymous, 2011, National Horticulture Board.http://www.nhb.gov.in/statistics/a rea-production-statistics.html as on 12.07.2012.

Calvin, M., Bassham, J. A., Benson, A. A., Lynch, V. W., Quellet and Schou, C., (1952), Nitrogen metabolism in plants, symposia. Exptl. Biol., 5: 284-305.

Dominquez, M. and Vendrell, 1993, Ethylene biosynthesis in banana fruit: evolution of EFE activity and ACC levels in peel and pulp during ripening. J. Hort. Sci., 68: 63-70.

Evans, L. T., Wardlaw, K. P. and Fisher, R. A., 1975, Crop Physiology. Cambridge University Press, London.

Farrag, A. A., Shehata, A. A. and Kandil, M. M., 1990, The effect of phosphorus and sulphur fertilizers on seed protein of broad bean plants. In: Proc. Middle East Sulphur Symp., February12-1, 1990, Cairo, p. 361-371.

Fisher, R. R. and Yates, F., 1963, Stastical tables for biological, agricultural and medical research. Sixth edition, Oliver and Boyd, Tweedale Court, Edinberg, pp. 747-77.

Gottreieh, M., Bradu, D. and Haleway, Y., 1964, A simple method for determining average fruit weights. Ktavim, 14: 161162. (C.f.: Lahav, E., 1972, Trop. Agric., 49: 321-325).

Harper, J. E., 1984, Uptake and organic nitrogen forms by roots and leaves. In: R.D. Hauck (ed.), Nitrogen in Crop Production, American Soc. Agron., Madison, WI, p. 165-170.

Kotur, S. C. and Keshava Murthy, S. V., 2008, Enhancing the fruit yield of 'Robusta' banana (Musa paradisiaca) by de-navelling and feeding Nitrogen, Potassium and Sulphur through the distal stalk end of the bunch. Indian J. 
Agric. Sci., 78 (2): 109-115.

Kumar, P. A. and Abrol, Y. P. 1990, Ammonia assimilation and reassimilation in higher plants. In: Y.P. Abrol (ed.), Nitrogen in Higher Plants, Res. Studies Press, Taunton, NJ. p. 159179.

Kurien, S., Sobhana, A. and Pushpalatha, P. B., 1999, Morphophysiological stages during various stages of finger development of banana $c v$. Nendran. Infomusa, INIBAP, France.

Lahav, E. and Turner, D. W., (1983), Banana Nutrition, IPIBull.No.7. International Potash Inst., Bern.

Marschner, H. 1995. In H. Marschner (Ed.). Mineral nutrition of higher plants 2nd ed. Academic Press, New York

Mengel, K. and Kirkby, E. A., 1987, Principles of plant nutrition. International Potash Institute, Bern: 436-437.

Mothes, K., 1961, The metabolism of urea and ureids. Canadian. J. Bot., 39: 17851807.

Mustaffa, M. M., Tanuja, B., Sivakumar, K. C., Kumar, V. and Sathiamoorthy, S., 2004, Effect of pre harvest treatments on bunch parameters, quality and shelf life of banana $c v$. Nendran. In Banana: Technological Advancements (Singh, H.P., and Uma, S. Eds), AIPUB, Trichy, p. 124-132.

Nalina, L. and Kumar, N., 2007, Yield and quality of banana $c v$. Robusta influenced by different fertilizer levels. Asian J. Hort., 2 (2): 1-3.

Nandan Kumar, C. P., Sathyanarayana, B. N., Naresh, P. and Lakshmipathy, M., 2011, Effect of certain preharvest treatments in improving the yield and quality of banana $c v$. Nanjangudu rasabale. $P l$. Arc., 11 (2): 677681.

Noggle, G. R. and Fritz, G. J., 1986, Introductory Pl. Physiol., Prentice Hall of India, Pvt. Ltd., New Delhi.
Pathak, N. L., Bauri, F. K., Misra, D. K., Bandyopadhyay, B. and Chaigiaborty, Y., 2011, Application of micronutrients on growth, yield and quality of banana. J. Crop Weed, 7 (1): 52-54.

Pattee, H. E. and Teel, M. R., 1967, Influence of nitrogen and potassium on variation in content of malate, citrate and malanate in non-nodulating soybeans (Glycine max). Agron. J., 59: 187-189.

Prasanna Kumari Amma, S, Babylatha, A. K, Pushkaran, K and Kurien, T. K., 1986, Studies on the effect of removing terminal hands and male bud on the yield and fruit size of banana Musa (AAB group) 'Palayankodan'. South Indian Hort., 34: 204-9.

Ramesh Kumar, A. and Kumar, N., 2010, Effect of post shooting spray of certain nutrients on yield and quality of banana cv. Neypoovan (AB). Agric. Sci. Digest, 30 (2): 125- 128

Ramesh Kumar, A., Kumar, N. and Jeyakumar, P., 2008, Effect of postshooting spray of Sulphate of Potash (SOP) on yield and quality of banana $c v$. Robusta (AAA- Cavendish). Res. J. Agri. Bio. Sci., 4 (6): 655-659.

Ramesh Kumar. A. and Kumar, N., (2007), Sulphate of Potash foliar spray effects on yield, quality and postharvest life of banana (India). Better Crops, 91 (2): 2224.

Ranganna, S., 1977, Manual of Analysis of Fruit and Vegetables Products. Tata McGrow Hill Publ., Co., Ltd., New Delhi.

Sateesh Kumar, S. and Bangarusamy, 2006, Effect of post shooting application of certain nutrients on fruit quality and post harvest storage life of banana $c v$. Rasthali (AAB). Pl. Arc., 6 (1): $201-$ 204.

Singh, H. P., 2001, Banana (In) Handbook of Horticulture, p152.Chadha K L (Ed). Indian Council of Agricultural 
Research, New Delhi.

Tisdale, S. L. and Nelson, W. L., 1966, Soil fertility and fertilizers, Macmillan Co., London.

Turner, D. W., 1997, In: Mitra S.K. (Ed.). Postharvest Physiology and Storage of Tropical and Subtropical Fruits. CAB International, New York, NY, pp. $47-$ 77.

Venkatarayappa, T., Narasham, B. and Venkatesan, C., 1976, Effect of postshooting application of urea on development and composition of banana fruit. South Indian. Hort., 19: 109-117.

Yadlod, S. S. and Kadam, B. A., 2008a, Effect of plant growth regulators and micronutrients on growth, yield and storage life of banana (Musa spp.) $c v$. Ardhapuri. Agric. Sci. Dig., 28 (4):304 $-306$.

Yadlod, S. S. and Kadam, B. A., 2008b, Effect of plant growth regulators and micronutrients on physical and chemical characters of banana (Musa spp.) $c v$. Grand Naine. Asian J. Hort., 3 (2): 436438.

\section{How to cite this article:}

Sreekanth, H.S., D. Thiphesha, K. Padmanabha, G.M. Vinay, A. P. Shivakumar and B.G. Jashmitha. 2018. Distill Stalk End Feeding (Bunch Feeding) can Improve the Quality and Yield of Banana cv. Robusta (AAA-Group) under Hill Zone of Karnataka (Zone-09). Int.J.Curr.Microbiol.App.Sci. 7(08): 2003-2013. doi: https://doi.org/10.20546/ijcmas.2018.708.231 